Tarih Kültür ve Sanat Araştırmaları Dergisi

Revue des Recherches en Histoire Culture et Art

مجلة البحوث التاريخية و الثقافية والفنية
Vol. 6, No. 3, June 2017

Copyright (c) Karabuk University

http://kutaksam.karabuk.edu.tr

DOI: $10.7596 /$ taksad.v6i3.932

Citation: Haghgoo, J., Ghaffari Hashjin, Z., \& Aghaei, M. (2017). A Review of the Turnaround in Iranian Foreign Policy during President Hassan Rohani's Administration. Journal of History Culture and Art Research, 6(3), 245-263. doi:http://dx.doi.org/10.7596/taksad.v6i3.932

\title{
A Review of the Turnaround in Iranian Foreign Policy during President Hassan Rohani's Administration
}

\author{
Javad Haghgoo" ${ }^{1}$ Zahed Ghaffari Hashjin ${ }^{2}$ \\ Mohammad Aghaei ${ }^{3}$
}

\begin{abstract}
The transition of power in the Islamic Republic of Iran is not only a change of guards in the different political and executive institutions during each electoral cycle but it also radically redefines the fundamental aspects of self-identity and the very definition of national interests and priorities and even how they should be defined. Upon the assumption of power by President Hassan Rohani in Iran, foreign policy of the government of the Islamic Republic of Iran has been exposed to tremendous developments. Prevalence of conservatism over revolutionary mindset, nationalism over transnationalism, and structuralism over agent-oriented trends are considered as the three main pillars of these developments. In Rohani's administration there is no longer any trace of the revolutionary behavior of Ahmadinejad's era. This turnaround in the Islamic Republic of Iran's foreign policy is not a new phenomenon. We have witnessed such a shift in Iranian foreign policy after the end of the 8year war with Iraq, albeit with different dimensions. An assessment of this issue would greatly enhance our understanding of the country's foreign policy. Accordingly, assessment of the real roots of these foreign policy shifts is the main objective of the present article. Evidently, the shift in foreign policy, more than anything else can be attributed to changes in the definition of the concept of national interests, and how each administration defines such national and transnational interests. Any shift or transformation in this concept, as the guiding principal of foreign policy, creates a context for the shift in the national priorities, orientations, and strategies in its interaction with its external environment. By highlighting the three concepts of "circulation of elites", "perception towards national identity", and "structural developments", the present article endeavors to review the causes of differing understandings of the concept of national interests in a specific period of the I.R. of Iran's foreign policy.
\end{abstract}

Keywords: Hassan Rohani, Islamic Republic of Iran, foreign policy, national interests, circulation of elites, Structural development, National Identity.

\footnotetext{
${ }^{1}$ Faculty of Science and Islamic Thought, University of Tehran, Tehran, Iran. E-mail: jhaghgoo@ut.ac.ir

${ }^{2}$ Faculty of Humanities, Shahed University, Tehran, Iran. E-mail: z-ghaffari@yahoo.com

${ }^{3}$ Faculty of Humanities, Shahed University, Tehran, Iran. E-mail: aghaei_1387@yahoo.com
} 


\section{1- Introduction}

After the victory of the Islamic Revolution in Iran, various perspectives have been raised over the foreign policy of the Islamic Republic. The diversity of these perspectives was rooted in the definition of national interest. Generally, two major perspectives emerged regarding this concept; the first, perspective was advocating the modern meaning of the concept of national interests, whereas the second perspective was highlighting the concept of the Islamic interests. Proponents of the first perspective were pursuing nationalism as their main priority in foreign policy. Referring to transnational ideals of the Islamic Revolution. The second perspective firmly believed that the interests of the "Islamic Ummah" should be incorporated in the foreign policy of the Islamic state. By adopting their own specific definition of the concept of national interests, followers of the second perspective argued that there is basically no contradiction between Iranian national interests and the interests of the "Islamic Ummah". They believed that it would be possible to reconcile both of these two domains of interests and objectives. Despite the fact that more than three decades has passed since the victory of the Islamic Revolution, differences of opinions over the concept of national interests has never subsided and advocates of each of these two camps have presented their specific definitions of the national interests and have shaped their foreign policy behavior based on their peculiar definitions, and objectives.

Considering this disagreement over the concept of "national interests", the present article argues that such a conceptual disagreement over theoretical foundations and practical representations has resulted in the adoption of fundamentally differing objectives, priorities, and orientations in foreign policy perspectives by different administrations. As a result, Iranian approaches and outlooks towards international arena have been exposed to profound shifts during different administrations foreign policy agendas and priorities. This is a phenomenon which is quite visible as we compare foreign policy approaches and objectives of President Ahmadinejad and President Rohani administrations.

In order to understand the foreign policy shift, three criteria of "circulation of elites", the "perception towards national identity", and the "structural developments", as well as to reveal the reasons of the developments in the concept of national interests, and consequently, the shift in foreign policy approaches during Rohani's administration compared with that of the previous administration. Accordingly, the first section of the article deals with the conceptual framework and reviews the relationship between the three selected criteria and the concept of the national interests and their effects on the foreign policies adopted by different administrations. The second section elaborates on Rohani's administration's foreign policy 
and its comparison with that of Ahmadinejad's administration within the mentioned conceptual framework.

\section{2- National interests and foreign policy: conceptual elements}

Assessment and analysis of a country's foreign policy would inevitably result in raising a fundamental question: Does foreign policy objectives meet a country's national interests requirements? This question indicates that the concept of national interest, regardless of immense ambiguities and complexities associated with it, is considered as the basic and essential element of foreign policy. Therefore, understanding the concept of national interests can be an indicator of the level of success or failure in foreign policy. At the same time, an accurate and transparent understanding of this concept can result in a proper assessment of orientations and priorities.

Within the framework of theoretical perceptions, both objectivist and subjectivist approaches elaborate on the issue of national interest and its shifts and developments. Whereas objectivists emphasize on material elements in foreign policy and consider these elements as vitally important in foreign policy shifts, subjectivists and more specifically constructivists mostly associate foreign policy shifts to the issues of identity and perception (Eftekhari, 2007). By adopting a combined outlook, we would, therefore, be able to review foreign policy shifts and developments based on the following three elements.

\section{2-1. Circulation of elites or shift in discourse atmosphere}

If we define foreign policy as the outcome of interaction between external and internal atmospheres of a country (Azghandi, 2010), elites and the discourse atmosphere created by them are considered as the most important internal elements. As representatives of people (in democratic societies), elites are outcomes of the society's expectations of existing potentials, especially that of the government. Nevertheless, democratization process has developed the principle of circulation of elites into a prevalent principle in contemporary period. For this reason, we cannot expect the everlasting governance of a particular group of elites. On the other hand, these elites are influenced by social status, values, and ideologies. Accordingly, they are representatives of a particular school of thought and affect the kind of decisions that are adopted. Based on this argument, foreign policy decision-making arena which gives meaning to the concept of national interests is greatly associated with the issue of elites. From such perspective, the concept of national interest has close relations with the ruling administration or the prevalent discourse. Practice of power and materialization of the 
predicates such as "interests" and "national" are within the framework of the elites' position. Therefore, when these predicates are exposed to change, the concept of national interests will experience shifts and developments (Tajik, 2007). Naturally, this process will result in the substitution of older discourses by new ones. In such circumstance, if the newly emerged discourse atmosphere has major differences with the previous objectives, especially in terms of signifiers, we can expect no transparent picture and no fix understanding of the concept of national interests.

\section{2-2. Perception on National identity}

Based on constructivist approaches towards foreign policy, realities are created by concepts, rules, and values. Accordingly, existing concepts, rules, and values in a given country, influence the kind of perception towards identity. Such an identity would, in turn, result in the evolution of national interests. National identity is the outcome of national and transnational norm. Through shaping different national roles, this identity strengthens the interests pursued by the country in its foreign policy. In other words, national identity is a factor that determines and evolves national interests and necessitates various national values and benefits (Dehqani Firouzabadi, 2007). Based on this argument, any identity or role shift will result in shifts in interests and values.

In terms of the first element, when a discourse or a set of different discourses represented by specific groups of elites become prevalent in the society, it will be quite natural that the outlook and values of the prevalent discourse influence the people's perception of the concept of national identity which consequently prepares the context for shifts in national interests. For instance, elites who prioritize religion and its resultant values in their discourse define a religious role for the country and plan the concept of national interests according to its definition.

\section{2-3. International developments}

While the first two factors dealt with internal elements that influence foreign policy and the concept of national interests, the third factor concentrates on international developments and its effect on foreign policy. In such circumstances, global and regional international developments can act as inputs to foreign policy objectives and transform its policies and priorities. Whereas structural realists believe that such an influence is an immediate and direct influence (Waltz, 1979), neoclassic scholars have presented a newer interpretation and argue that this structural influence in foreign policy orientation is an indirect influence resulting 
from the outcome of internal elements such as elites' perceptions and consciousness (Moshirzadeh, 2007). Therefore, the concept of national interests is greatly influenced by international developments during various stages.

\section{3- Conceptual Shift in the concept of national interests during Hassan Rohani's administration}

Based on the mentioned criteria, the Islamic Republic of Iran as a nation-state is inevitably obliged to play its role as an actor in foreign domains and embark on policy-making initiatives in this arena. Due to the activities of elites and their inevitable circulation and also due to international developments, Iranian foreign policy cannot sustainably maintain a single concept of national interests and its internal priorities. As a result of the transition of elites in various stages of post-Revolutionary period in Iran and concurrent with international developments, Iranian foreign policy has experienced shifts in the basic concept of national interests as a result of which the country has been exposed to shifts in objectives and strategies. Basic shifts in the foreign policy of President Rohani's administration compared with that of President Ahmadinejad's administration should be considered as a good example of the adoption of such an approach.

\section{3-1. Circulation of elites and shift in the definition of national interests}

Circulation of elites and substitution of foreign policy decision-makers are basic factors for shifts and developments in the concept of national interests. Differences of opinions, emergence of a new literature in the political arena of the country, and even shifts in politicians' perceptions of different concepts indicate that Islamic Republic of Iran has opened a new chapter in its foreign policy during President Rohani's administration. Transformation of political concepts, especially fundamental concepts such as national interests which had been associated with various definitions since the early days after the victory of Islamic Revolution, were at the center of these developments. Nevertheless, such developments had been experienced in past decades. Many scholars and thinkers consider Rohani administration's foreign policy as a return to that particular period of the history of Islamic Revolution when the former president Akbar Hashemi Rafsanjani was leading the executive branch.

Based on this belief, Rohani's understanding of the concept of national interests and consequently his administration's behavior in foreign policy arena are precisely similar to those of the pragmatic administration headed by Rafsanjani. This similarity becomes more 
salient if we realize that Ahmadinejad's revolutionary and radical foreign policy had extensive similarities with the foreign policy prevalent before Rafsanjani's presidency, i.e. during the premiership of Mir Hussein Mousavi. It is based on this outlook that we can describe Ahmadinejad's tenure as a return to the past history of the Islamic Republic after a 16-year hiatus (Azghandi, 2010). As a new generation of conservatives and despite the fact that religious elites of Iranian society were opposed to him, Ahmadinejad relied on his status among the poor and revolutionary classes and ascended to power (Sherrill, 2014).

If we draw a diagram of foreign policy developments in the Islamic Republic of Iran since Mousavi's administration up to the beginning of Ahmadinejad's ascendance to power, we can observe that this process moves from a mere idealistic and totally ideological outlook towards relatively realistic and pragmatic approaches. Nevertheless, when Mahmoud Ahmadinejad formed his cabinet, Islamic Republic of Iran's foreign policy, which had been gradually associated with relative rationalism, was exposed to a severe shock and disruption. In other words, détente and confidence-building were substituted by a period of tension and confrontation in international relations (Azghandi, 2010). During this period, Iranian foreign policy was exposed to profound shifts and developments and despite maintaining its fundamental and fixed foreign policy principles, it experienced a profound swing in behavior and diplomacy (Dehqani Firouzabadi, 2012). Compared with previous periods, Iranian foreign policy adopted different behavioral principles in this period (Dehqani Firouzabadi \& Radfar, 2010).

Ahmadinejad's mindset and that of his cabinet members and advisors were rooted in radical conservative or neoconservative trends. Relatively young elites who had assumed the responsibility of administrative affairs of the country were greatly influenced by IslamicShiite values and norms. In addition, Ahmadinejad's statements indicated that he is first of all interested in the serious materialization of fundamentalism in domestic policy and also in the disruption of existing order in the world through the export of revolution (Azghandi, 2010). Ahmadinejad's ideological norms were mainly reflected in his dealing with the nuclear issue, his emphasis on Iran's inalienable rights to obtain peaceful nuclear energy, and his efforts to play the superior role in the Persian Gulf and the Middle East through reliance on nuclear and military power (Azghandi, 2010).

Since the very early days of his election as the president of Iran, Mahmoud Ahmadinejad referred to concepts such as "the role of justice and spirituality in global developments" (Mottaghi, 2005), "the necessity of creating balance between rights and responsibilities in international politics" (Gharibi, 2008), "critical outlook towards international organizations" (Gharibi, 2008), "look-to-east policy" (Mottaghi, 2005), and "revival of South-South foreign 
policy approach" (Mottaghi, 2005) as his main foreign policy priorities. After assuming power, Ahmadinejad questioned the structure and nature of the international system and talked of the necessity of adopting an aggressive policy towards the West (Azghandi, 2010). According to Hamid Molana and Manouchehr Mohammadi, two major theorists of Ahmadinejad administration's foreign policy, predicates such as "the myth of holocaust, basis of Zionism's hegemony in the world", "wiping out Israel from the map of the world", "forming an anti-imperialism united front", "the role of Mahdaviat in foreign policy", "unity of the Islamic world", "and aggressive policy in nuclear issue" constituted basic strategies in Ahmadinejad's foreign policy (Molana \& Mohammadi, 2009).

The strategy of justice and mutual rights was considered as the main ingredient of Ahmadinejad administration's foreign policy. This strategy upholds that foreign policy cannot be materialized and maintained without justice (Eivazi \& Navazney, 2004). Ahmadinejad was the most important decision-maker in Iranian foreign policy during his eight years of presidency and his negative and at times hostile outlook towards existing international system, international organizations, and Western values (Molana \& Mohammadi, 2008) had a profound influence on his attitudes and strengthened idealistic outlooks during this period. Ahmadinejad's outlook was based on a realistic pivotal power with an emphasis on the importance of obtaining military power and rejecting the functionality of international organizations (Molana \& Mohammadi, 2008), along with an ideological outlook towards foreign policy objectives.

Revisionist nonalignment was Ahmadinejad administration's foreign policy strategy and orientation. Within the fundamental principle of nonalignment with global hegemonic powers, such a strategy is associated with revolutionary and ideological commitments and missions of the Islamic revolution. Therefore, this strategy pursued something more than the conventional nonalignment. In other words, it not only rejected any dependency on global powers, but also concentrated on disrupting the existing international order. This objective could understandably be achieved through infrastructural shifts in principles of the existing unfavorable global order (Dehqani Firouzabadi, 2010).

In terms of social origins, family education, political inclination, and numerous other factors, officials of Ahmadinejad's administration, especially high ranking members in the ministry of foreign affairs, had their own peculiar characteristics: they were mainly traditionalists, apathetic towards strangers, idealists, reaction-oriented, critical of former administrations' foreign policies, fundamentalists, and inflexible (Azghandi, 2010). Upon the election of Hassan Rohani as Iran's president, attitudes of Iranian ruling political elites altered to a great extent. Rohani was the only moderate candidate in the 2013 presidential elections in Iran 
(Sherrill, 2014). Since his ascendance to power in that year, he has introduced extensive changes in Islamic Republic of Iran's foreign policy (Sherrill, 2014).

Since the time they assumed the responsibility of the executive branch, Rohani and his administration have envisaged several main objectives for their administration. For them, economic settlement, management, and international crises were prioritized over other objectives. They considered these crises as the outcome of inefficiency and inadequacy of Mahmoud Ahmadinejad's administration. For the Rohani administration, settlement of international disputes over Iran's nuclear issue was more important and prioritized over other issues. According to President Rohani, settlement of a great number of current problems in Iranian society, especially economic problems, is dependent on the settlement of Iran's nuclear dispute with the West (Bastani, 2014). In criticizing the outlook of the former president's administration towards international issues, especially Iranian nuclear issue, Rohani has unexpectedly challenged his opponents on numerous occasions and even has referred to them as "cowards" (Bastani, 2014).

Therefore, saving Iran from international isolation has been one of Rohani's main objectives (Shanahan, 2015). Since the first year of his presidency, Rohani emphasized the revival of Iran's international image as a national priority for his administration. One of the salient and peculiar features of President Rohani's cabinet is the fact that a large number of his cabinet members are graduates from Western universities. Certainly, it does not mean that they are supporters of Western social values. Nevertheless, their familiarity with the West has provided them with a better understanding of Western social values (Shanahan, 2015). During the nuclear talks, Rohani was able to create a situation which Iranian and American officials embarked on face-to-face negotiations. It was a great step towards the improvement of Iranian fragile relations with United States. President Rohani endeavors to generalize this pattern to a more extensive scope, a scope whose boundaries are still ambiguous (Shanahan, 2015).

According to Rohani and his accompanying elites, Iran should refrain from having a permanent enemy. He believes that Iran can settle its problems, especially in the economic arena, through adopting pragmatic policies under JCPOA and transform Iran into an important hub for international trade and transportation (Katzman, 2016). He has referred to Iran's nuclear deal with the West as an unprecedented opportunity for creating an atmosphere of friendship and cooperation with all the countries of the world (Erdbrink, 2015). Improvement of Iran's flimsy foreign policy was one of Rohani's major promises during his election campaigns. Rohani argued that 8 years of Ahmadinejad's presidency has imposed great harms on Iran's relations with the outside world. President Rohani believed that reduction of international sanctions can improve Iran's economic condition (Juneau, 2014). 
Compared with his main rivals among presidential candidates, Rohani showed a more moderate approach (Sherrill, 2014). In terms of foreign policy, he adopted an approach similar to that of the former president Hashemi Rafsanjani's. This similarity was so extensive that many officials of Rafsanjani administration received high-ranking positions during Rohani's presidency and revived their control over administrative affairs of the country after two decades. The vice president, and many presidential advisors, government spokesman, and ministers of defense, foreign affairs, petroleum, roads and urbanization, communication and information technology, intelligence, health, labor, and agriculture in Rohani's administration are members of moderate parties and factions (Mehr News Agency, 05/08/2013).

Hassan Rohani has extensive similarities with Hashemi Rafsanjani. Rafsanjani was an example of realist revolutionary leader who always endeavored to stand against extremist trends. Compared with the period of eight-year war with Iraq, shifts in determining and understanding the concept of national interests were so tangible during Hashemi Rafsanjani's presidency that Americans had coined Rafsanjanism as a modification trend in Iran's internal and external policy approaches (Hermidas Bavand, 2001). During this period, Iranian elites were mostly concentrated on internal issues and, for them, materialization of national interests of the I. R. of Iran in foreign policy arena based on internal parameters and considerations were highlighted by the then-administration. In other words, behavioral patterns of confrontation and expansionism were shifted to reconciliation and coexistence patterns, respectively, during Rafsanjani administration.

According to Rohani, favorable foreign policy is a policy which reduces the costs and increases the benefits. Emphasizing on the necessity of realism, he believes that ideals, too, can be materialized through realism (Entekhab News Agency, 05/08/2013). He emphasizes on the necessity of cooperation with different countries in the world and argues that it is impossible to cut relations with other nations. During his election campaigns, Rohani described constructive interaction and détente with the global community as his main objective in foreign policy arena (Iranian Labor News Agency (ILNA), 2013/06/13). Based on his election campaign and his behavior during the past couple of years, we can describe his foreign policy as a policy founded on "realistic idealism" (Karimi, 2013), "calculative pursuit for international power", "interaction with international order", "moderation-based concept of balance of power", "détente especially with neighbors based on cost-benefit analysis" (Karimi, 2013), and "abstaining from using harsh language against the enemy and being aware of enemy's plots" (Iranian Student News Agency (ISNA), 2013/07/14). Rohani believes that realism has no contradiction with idealism and pursuance of values; rather, it provides a context for each of them (Alipourian \& Nouri Asl, 2014). 


\section{3-2. Shift in understanding the national interests and its definition}

After the victory of Islamic Revolution in Iran, values based on Islamic Shiism became the most important source for creating unity in Iranian society. Therefore, accepted values of the previous regime were constrained or totally rejected. This was a destiny which befell on nationalism and nonreligious pillars of Iranian identity. Based on an almost collective agreement during the first decade after the victory of the Islamic Revolution, religious approach became so prevalent that national identity was considered synonymous and equal to religious identity and other aspects of identity were marginalized. After the end of the IranIraq war and with the emergence of Hashemi Rafsanjani as president, the country moved towards reconstruction and renovation which forced to redefine the concept of Iranian identity. Based on this definition, Iranian identity was a combination of Iranian nationalism and religious beliefs. After the presidency of Rafsanjani's and during Khatami, Ahmadinejad, and Rohani administrations, Iran has witnessed different interpretations of the concept of national identity. Differing interpretations of this concept by Ahmadinejad and Rohani administrations was an effective element in their dissimilar understandings of the concept of national interests as well as their adoption of different foreign policy orientations and objectives.

In terms of national interests, Ahmadinejad considered himself as a follower of Ayatollah Khomeini, founder of the Islamic Republic. By prioritizing Islam over Iran, he emphasized on the definite superiority of Islamic interests over national interests. According to Ahmadinejad's outlook, national government should act within the framework of Islamic ideology and worldview. Therefore, according to Ahmadinejad, his government has no secular nature. Rather, it is rooted in religious and Islamic understanding. This discourse looks at government and state from the perspective of ethical politics. Establishment of a religious society based on timeless and placeless principles and values of Islamic Sharia is the center of gravity of this discourse.

In Ahmadinejad's perspective, Islamic Revolution and its ideals, principles, and values are fundamental and structural elements that constitute and define Iranian national identity. Based on this perspective, Islamic Republic of Iran's identity is the resultant accumulation of the elements of "Islamic identity", "Islamic Revolution", and "Iran." Compared with "Iranian nationalism", these elements play more important roles in the evolution of Islamic Republic of Iran's identity. During Ahmadinejad's tenure, the Islamic-Revolutionary nature and identity of the Islamic Republic of Iran determined and defined the meaning of national interests and objectives (Eivazi \& Navazney, 2008). 
Mahmoud Ahmadinejad considered the extension of Islamic Revolution discourse and introduction of Islamic society pattern to human beings as one of missions of Iranian foreign policy. According to Ahmadinejad, "... we are tasked to spread out the message of Islam throughout the world" (Dehqani Firouzabadi \& Radfar, 2010). He argued that Islamic Republic's mission is not just limited to the establishment of an Islamic society and state within Iran. Its greater mission and responsibility, Ahmadinejad argued, was the introduction of a developed and fair Islamic state to other nations (Dehqani Firouzabadi \& Radfar, 2010).

Ahmadinejad's foreign policy once again subjected the national interests to Islamic and ideological expediencies (Azghandi, 2010). During his administration, the concept of national interests was mostly based on idealistic and value-oriented considerations and its realistic dimensions had been ignored.

During the two terms of Ahamadinejad's presidency, geographical boundaries were substituted by ideological ones and nationalist discourse was replaced by religious discourse. In such an environment, Islam became the identity-creating element which defined one's "self" and "others" and Islamicism acted as the center of gravity for the Iranian national identity. Also, Ahmadinejad administration labeled itself as "justice-expansion government", "anti-tyranny government", "advocate of Islam and Shiism", and "supporter of liberation movements."

According to this perspective, national interests are associated with different objectives, such as development of international justice, abidance by responsibilities, and refusal of hegemony of “arrogant powers”. It is coupled with revolutionary spirit and efforts for end-of-the-time preparations. Therefore, national interests are not specified by external factors and conditions; rather, they are mainly determined by pre-ordained, unchangeable, and relatively fixed ideological motivations.

Upon the ascendance of Rohani to power, Iranian foreign policy procedures prevalent during Ahmadinejad's administration changed dramatically. If we consider Ahmadinejad's justiceoriented discourse, which was associated with features such as return to the early ideals of Iranian Islamic Revolution and preference of Islamic expediencies over national interests, as the prevalent discourse during his presidency, détente-and-moderation-based discourse (Alipourian and Nouri Asl, 2014) with features such as realism and preference of national interests over Islamic expediencies should be described as the prevalent discourse during President Rohani's administration.

Historically, I. R. of Iran's foreign policy has been fluctuating between two paradigms: first, active isolationism; and second, paradigm of national-interest-based internationalism, which 
supports international commitments of I. R. of Iran's government in order to support and develop Iranian interests. The second paradigm is concentrated on Iranian peculiar geography. This paradigm argues that Iran cannot be internationally isolated; therefore, this country's international interaction and cooperation is inevitable. Certainly, Rohani is not an isolationist person. He is perhaps not an absolutely internationalist leader, due to his realism, however, he has undoubtedly a positive outlook towards international cooperation (Chatham House: Workshop Summary, August 2016). With the substitution of Ahmadinejad's ideological cabinet by Rohani's technocrat cabinet, new perceptions in the interpretation and clarification of political concepts were imposed on Iranian elites (Azghandi, 2002). One of these concepts, perhaps the most important of them, was the concept of national interests (Azghandi, 2002). It was a vitally important concept that was closely associated with the kind of perception over the concept of national identity among elites.

Rohani administration's outlook towards the issue of national identity should be considered as a continuation of Rafsanjani administration's outlook. According to this view, national identity is a combination of Iranian nationalism and Islamic beliefs. Rohani administration's attitude towards groups such as the Lebanese Hezbollah and the Yemeni Houthis and this administration's stance towards Syrian developments are clear indications of a shift in the concept of national identity during Rohani's presidency. Compared with Ahmadinejad's period, Iran's support of such groups has significantly reduced in President Rohani's administration. For this reason, Rohani has been criticized by some of the military powerhouses, such as Islamic Revolutionary Guards Corps (IRGC).

As it was pointed out Rohani's perception of the concept of national identity was opposed to that of his predecessor. From Rohani administration's point of view, Islamic Republic of Iran's national interests are not necessarily identical with Islamic interests. Based on this perspective, in case of any contradiction between these two interests, the administration is required to prioritize national interests over the religious stances. Accordingly, I. R. of Iran's government is endeavoring to maximize Iranian national interests in its modern sense based on internal parameters and domestic potentials and constraints.

\section{3-3. Structural developments and shifts in the definition of national interests}

During Ahmadinejad's administration, both the world and the region were exposed to extensive developments. Some of these developments continued even after Rohani assumed power. Iranian nuclear dossier was one of these major issues. Being referred to UN Security Council, Iranian nuclear issue had become a security issue with international dimensions. 
Iran's dispute with Western countries had reached its culmination during Mahmoud Ahmadinejad's presidency. Nevertheless, this issue went through a different course after Rohani's election. At the same time, President Obama's administration showed an interest in settling this issue. It is not an exaggeration if we argue that Iranian nuclear deal was the most important development which had numerous regional and international achievements for all parties involved. ${ }^{4}$ This different situation was, more than anything else, the result of a shift in American leadership under Barack Obama. The United States was seeking an opportunity to open talks with Iran after the presidency of Ahmadinejad's in order to settle the nuclear dispute. In other words, with the assumption of power by Hassan Rohani, Western governments, especially the United States, became optimistic towards the new Iranian administration and the shadow of war which had been created during Ahmadinejad's tenure was replaced by a context for cooperation and interaction with Iran. Undoubtedly, the nuclear deal should be considered as an outcome of the adoption of this different approach of major global powers towards the new Iranian administration. ${ }^{5}$

Concurrent with the beginning of Rohani's presidency, the region and the world witnessed many more developments other than those related to Iranian nuclear issue. These developments acted as inputs from outside players and resulted in the adoption of a specific definition of the concept of national interests by Rohani's administration and consequently tangible turnarounds in the foreign policy of the I. R. of Iran. Compared with the developments of previous administration, the most important developments during Rohani administration can be summarized as follows:

1. End of the honeymoon of American relations with Persian Gulf Cooperation Council member states and Turkey (Krieg, 2016). During Rohani's presidency, President Barak Obama believed that the United States should no longer give free rides to Arab nations (Terrill, 2015). In addition, US-Turkey relations were to some extent deteriorated during Rohani's administration. Some observers even talked of the US involvement in the failed coup of July 2016 in Turkey (Mehr News Agency (MNA), 2016/07/14). During Ahmadinejad's presidency, on the contrary, America's relations with these

\footnotetext{
${ }^{4}$ Although it seems that the new US administration under President Donald Trump is willing to manipulate, revise, or even annul the Joint Comprehensive Plan of Action (JCPOA), if possible, this agreement is an international agreement over Iranian nuclear activities between Iran and global powers. Meanwhile, the UN has issued a resolution endorsing this agreement. Therefore, it will be quite difficult for the US to manipulate Iran nuclear deal.

${ }^{5}$ Obama administration's outlook towards Rohani's administration was so different that both sides tried to meet each other during Rohani's first trip to New York for participating in the UN General Assembly. Their efforts resulted in a telephone conversation between the two presidents while Rohani was in the airplane on his way back to Iran.
} 
countries were friendlier both under President George Bush and President Obama administrations.

2. Intensification of Russian-American differences during Obama administration; Ukrainian and Syrian crises, especially Russia's direct military interference in Syria, were important developments that were quite effective during Rohani's presidency. Of course, differences between Washington and Moscow have a long history and are not peculiar to this period only. Nevertheless, it seems that the gap between the two Cold War-era rivals has different dimensions during these recent years. This is the result of Russia's efforts to revive its lost dignity under Vladimir Putin's leadership.

3. Escalation of tensions between Iran and Saudi Arabia as two military and economic powers in the region. Intensification of Tehran-Riyadh differences is the outcome of their efforts to settle political and security accounts with each other in areas such as Syria, Iraq, Lebanon, Bahrain, and Yemen. However, emergence of a group of new and younger leaders in Saudi Arabia who nurture radical anti-Iranian feelings further complicated the already tense relations between Iran and Saudi Arabia. During Ahmadinejad's presidency, a group of experienced, tolerant, and moderate figures were ruling over Saudi Arabia. For instance, we can review contradictory stances adopted by Saud Al-Faisal and Adel Al-Jubair, previous and current foreign ministers of Saudi Arabia, respectively, regarding regional countries, especially Islamic Republic of Iran.

4. Ever increasing security rivalry between Iran and Turkey over Syrian and Iraqi crises. We ought to remember that Iran and Turkey enjoyed friendly relations, especially during 2012. For instance, Iran, Turkey and Brazil issued a tripartite declaration for settling Iranian nuclear issue in that year which was known as "Tehran Declaration." (Mehr News Agency (MNA), 2010/05/17). It should be pointed out, however, that during Ahmadinejad's administration, Iran was dealing with an Erdogan that his place was different than how he has developed his recent positions.

5. Iran-US secret nonmilitary and security cooperation in Iraq for confrontation against ISIS (Krieg, 2016). Some eyewitnesses have reported of the simultaneous presence of Iranian and American military advisors in a military base in Iraq. Meanwhile, some sources have talked of a secret diplomacy between Iran and the US to stand against ISIS in Afghanistan. Iran did not have any such cooperation with the United States during Ahmadinejad's presidency. 
6. Fall of oil prices in global markets (www.nasdaq.com). Compared with 2012, Iran lost one fourth of its oil revenues in 2013. Considering the rentier nature of Iranian economy and maximum dependency of its government to oil revenues (Mahdavy, 1970) rapid declining oil prices, compared with skyrocketing oil prices during Ahmadinejad administration, was a clear structural development that influenced the definition of the concept of national interests by Rohani administration.

In addition, there were some other structural developments at both regional and international levels which influenced President Rohani administration's foreign policy. Completion of Habshan-Fujairah oil pipeline ${ }^{6}$ can be highlighted as one of these developments. Nevertheless, the mentioned six developments have, in comparison with other developments, been more effective in this regard.

\section{4- Conclusion}

As one of the most important policy-making arenas for interacting between internal and external environments of countries, foreign policy has always been influenced by the kind of definition and progression that they provide for the concept of national interests. Formulation of strategies, orientations and application of instruments for the materialization of objectives in external environment are dependent on the kind of theoretical consensus among elites of that society. Therefore, any shift in the definition of the concept of national interests can influence foreign policy and its associated strategies.

Islamic Republic of Iran's foreign policy has always been an arena which reflected the developments in the concept of national interests and consequently the shifts in foreign policy priorities and orientations. Circulation of elites, perception on national identity, and structural developments are three factors that have, during different periods of Islamic Republics foreign policy, contributed to the development of the concept of national interests. While the mentioned three factors have always been influential during different periods, one factor has been more significant. The interim government, which was formed a couple of days before the victory of the Islamic Revolution in Iran, ended in the so-called "circulation of elites", which resulted in a shift in their perception of the concept of national identity. The interim government defined national interests within the framework of Iran and Iranian national identity. Nevertheless, during Iran-Iraq war the concept of national interests was redefined.

\footnotetext{
${ }^{6}$ With the completion of this pipeline, Rohani administration was no longer able to maneuver over Iran's strategic advantage in blocking the Strait of Hormuz. During his presidency, Ahmadinejad and many Iranian military commanders whose mindset were similar to that of him were repeatedly referring to this strategic advantage.
} 
During this period, the concept of national interests was defined at a higher level, i.e. within the framework of the interests of the "Islamic Ummah" and the "Islamic world". This shift in definition of the concept of national interests was due to the mindset of elites, primary war conditions, and structural pressures. When Hashemi Rafsanjani became president, his administration, under internal pressures and external realities, had to develop a new definition for the concept of national interests in order to meet the needs of the country. Khatami and Ahmadinejad's administrations, too, were influenced by these factors. Due to his personal characteristics, Khatami defined foreign policy and national interest priorities within a cultural environment. However, when Ahmadinejad became president, the concept of national interests was, compared with previous administration, radically changed, due to the new presidents world-view and self-perception. At the same time, the international community was exerting greater pressures on Iran. As a result, Ahmadinejad administration had its own definition of the concept of national interests.

With the assumption of power by Hassan Rohani and the shifts in all the three factors, i.e. circulation of elites, the kind of perception towards national identity, and structural developments, the newly emerged elites redefined the concept of national interests as a result of which we witnessed a kind of shift in foreign policy orientations and objectives of the Islamic Republic of Iran. In this period, the revolutionary mindset, trans-nationalism, and agent-oriented trends that were common during Mousavi and Ahmadinejad administrations were replaced by conservatism, nationalism, and structuralism that were prevalent during Hashemi Rafsanjani and Khatami administrations.

It is quite clear that turnarounds in Islamic Republic foreign policy are not newly emerged nor unprecedented phenomena. A review of specific periods of Islamic Republic of Iran's foreign policy and their relations with the concept of national interests indicate that fundamental shifts and developments in this concept are associated with the rise and fall of cabinets and presidents. Despite the fact that these shifts and developments are inevitable outcome of the circulation of elites, the principle of sustainability in foreign policy emphasizes on the necessity of preserving past achievements and act upon common bases. This is an issue which can be described as the missing link in Iranian foreign policy. 


\section{References}

A Review of Political Records and Orientations of Rohani's proposed Ministers: Seven Reformist and Two Principalist Ministers in the Cabinet of the Moderate Presicent (2013). Mehr News Agency. 05/08/2013, at: http://www.mehrnews.com/news/2110202

Alireza Azghandi, A. (2002). Islamic Republic of Iran's Foreign Policy. Tehran: Qoumes Publication Co. p. 16. quoted from: Fuertig Henner, F (2002). Islamische Weltauffassung und aussenpolitische Konzeptionen. Berlin: Verlag das Arbisch. p. 64.

Alireza Karimi, A. (2013). Rohani's Possible Foreign Policy within the Context of Theories. Fars News Agency (FNA). 2013/06/29 at: http://www.farsnews.com/newstext.php?nn=13920408001025

Andreas Krieg, A. (2016). Externalizing the burden of war: the Obama Doctrine and US foreign policy in the Middle East. The Royal Institute of International Affairs.

Azghandi, A. (2010). Frameworks and Orientations in the Islamic Republic of Iran's Foreign Policy. Tehran: Qoumes Publication Co.

Clifton W. \& Sherrill, C. W. (2014). Why Hassan Rouhani Won Iran's 2013 Presidential Election, Middle East Policy. Vol. XXI, No. 2. pp. 64-75.

Davood Hermidas Bavand, D. (2001). Scientific Dialogue, National Interests, and Foreign Policy: Iran and US Relations? Strategic Studies. Nos. 11 and 12. pp. 11-22.

Dehqani Firouzabadi, J. \& Radfar, R. (2010). Patterns of the Export of Revolution (2th Ed.)Tehran: Imam Sadiq (PBUH) University Press. p. 189.

Dehqani Firouzabadi, J. (2007). Identity and Interests in the Islamic Republic of Iran's Foreign Policy. In Kiani.D (ed.). Islamic Republic of Iran's National Interests (P.149). Tehran: Research Institute of Strategic Studies.

Dehqani Firouzabadi, J. (2012). Islamic Republic of Iran's Foreign Policy, Tehran: SAMT Publication Co., 2012, p. 512.

Eftekhari, A. (2007). Expediency and Interests: Compatibility between Religious Expediency and National Interests in the Islamic Republic Pattern of Governance. In Davood Kiani, D (ed). Islamic Republic of Iran's National Interests (P.P 38-45). Tehran: Research Institute of Strategic Studies.

Eivazi, M. R \& Navazney, A. (2008). An Analysis of President Mahmoud Ahmadinejad's Foreign Policy. Rahbord Yas. No. 14. pp. 209-230. p. 209.

Erdbrink, T. (2015). Post-Deal Iran Reappraising ‘Great Satan’. New York Times. September 18, 2015.

Hamid Molana, H. \& Mohammadi, M. (2009). Iranian Foreign Policy during President Ahmadinejad's Administration (3th Ed.). Tehran: Dadgostar Publication Co. pp. 157-200.

Hassan Rohani: We Should Remove the Security Umbrella over Cinema and Music (2013). Entekhab News Agency. 05/08/2013, at: http://www.entekhab.ir/fa/news/109542

Hussein Bastani, H. (2014). How Powerful is Rouhani in the Islamic Republic?. CHATHAM HOUSE: Research Paper. p. 2, at: https://www.chathamhouse.org/sites/files/chathamhouse/field/field_document/20141124Rouhaniislam icRepublicBastani.pdf 
Hussein Mahdavy, H. (1970). Patterns and Problems of Economic Development in Rentier State: the Case of Iran. In Cook, M.A. (Ed). Studies in Economic History of the Middle East. London: Oxford University Press.

Iran's Politics and Foreign Policy (2016). Chatham House: Workshop Summary. August 2016, p. 6. at: https://www.chathamhouse.org/sites/files/chathamhouse/events/2016-03-13-irans-politics-foreignpolicy-workshop-summary.pdf

Juneau, T. (2014). Iran under Rouhani: Still Alone in the World". Middle East Policy, Vol. XXI, No. 4. pp. 92-104, pp. 100-101.

Katzman, K. (2016). Iran’s Foreign and Defense Policies. Congressional Research Service. p. 3.

Kenneth Waltz, K. (1979). Theory of International Politics. New York: Random House.

Mohammad Rahim Eivazi, M. R. \& Ali Navazney, A. (2004). A Comparative Assessment of President Ahmadinejad's and President Rohani's Foreign Policy toward the United Nations. Strategic Defense Studies. No. 58. pp. 39-74, p. 43.

Mohammad Reza Tajik, M. R. (2007). The Iranian Man and National Interests: A Paleontological and Genealogical Review. In Kiani.D (ed.). Islamic Republic of Iran's National Interests (P.31). Tehran: Research Institute of Strategic Studies.

Moshirzadeh, H. (2007). The Shift in Theories of International Relations. Tehran: SAMT Publication Co.

Mottaghi, E. (2005). An Assessment of President Ahmadinejad Administration's Foreign Policy: the Prevalence of Myth over Reality. Hayat-e No-e Eqtesadi Journal. 03/09/2005.

Rodger Shanahan, R. (2015). Iranian foreign policy under Rouhani. Low Institute for International Policy. p. 2, at: https://www.files.ethz.ch/isn/188299/iranian-foreign-policy-under-rouhani.pdf

Rohani: Respect and Authority for the Majlis should be Revived (2013). Iranian Student News Agency (ISNA). 2013/07/14, at: http://www.isna.ir/news/92042314473

Saeed Gharibi, S. (2008). President Ahmadinejad Administration's Foreign Policy. Imam Khomeini International University, Website for Iranian Scientific Articles.at: http://www.articles.ir/article2453.aspx

Suspicious Coup in Turkey/Iran reacted perfectly in this regard (2016). Mehr News Agency (MNA). 2016/07/14. at: http://www.mehrnews.com/news/3714292

Tahmasb Alipourian ,T. \& Nouri Asl, A. (2014). Discourse Development or Shift in the Foreign Policy of the Islamic Republic of Iran: A Comparison of Foreign Policy during President Ahmadinejad and President Rohani Administrations. Political Studies. No. 25, pp. 79-108, p. 102.

Terrill, W. A. (2015). Arab threat perceptions and the future of the US military presence in the middle east. SSI and U.S. Army War College Press. at: http://www.strategicstudiesinstitute.army.mil/pdffiles/pub1297.pdf

We Are Far From Extremism and Irresponsible Behavior (2013). Iranian Labor News Agency (ILNA) 2013/06/13 at: http://www.ilna.ir/\%D8\%A8\%D8\%AE\%D8\%B4\%D8\%A7\%D8\%AE\%D8\%A8\%D8\%A7\%D8\%B1-105/80919-\%D9\%85\%D8\%A7\%D8\%A7\%D8\%B2-\%D8\%A7\%D9\%81\%D8\%B1\%D8\%A7\%D8\%B7\%DA\%AF\%D8\%B1\%DB\%8C 


\section{Other Sources}

"Crude Oil WTI", at: http://www.nasdaq.com/markets/crude-oil.aspx?timeframe=10y

The 10-Article Agreement among Iran, Turkey, and Brazil/IAEA's Supervision over the Exchange of Fuel (2010). Mehr News Agency (MNA). 2010/05/17 at: http://www.mehrnews.com/news/1084432.

http://onlinelibrary.wiley.com/doi/10.1111/1468-2346.12506/full

https://fas.org/sgp/crs/mideast/R44017.pdf 